\title{
PELATIHAN LITERASI KEUANGAN DAN E-COMMERCE BAGI PELAKU UKM KERAJINAN SULAMAN DAN BORDIR DI KOTA PADANG SUMATERA BARAT
}

\author{
Rosyeni Rasyid ${ }^{*}$ \\ Muthia Roza Linda ${ }^{2}$ \\ Erni Masdupi ${ }^{3}$ \\ Thesa Alif Ravelby 4 \\ Suhery ${ }^{5}$ \\ $1^{*}, 2,3$ Jurusan Manajemen, Fakultas Ekonomi Universitas Negeri Padang, Padang, Indonesia \\ 4,5Sekolah Tinggi Ilmu Ekonomi Perdagangan, Padang, Indonesia \\ rosyenirasyid@gmail.com $^{\left.1^{*}\right)}$ \\ muthia@fe.unp.ac.id ${ }^{2}$ \\ emasdupi@gmail.com ${ }^{3}$ \\ thesaalif5743@gmail.com ${ }^{4}$ \\ suheriasia@gmail.com ${ }^{5)}$
}

Kata Kunci: [Literasi

Keuangan, Website,

Pengelolaan Keuangan,

Transaksi online]

Published by:

Abstrak: Latar belakang program pengabdian adalah minimnya akses pengusaha kerajinan di kota Padang terhadap lembaga keuangan dapat disebabkan karena masih rendahnya tingkat literasi keuangan dari pelaku usaha kerajinan. Metode pengabdian masyarakat ini adalah (1) Workshop mengenai literasi keuangan; (2) Pendampingan dalam melakukan perdagangan melalui internet (Ecommerce) dengan membuatkan website yang dapat dikelola oleh kelompok mitra dalam pemasaran produknya. Hasilnya, para pengrajin sulaman dan bordir diberikan pengetahuan dan wawasan mengenai apa itu literasi keuangan melalui inklusi keuangan dan bagaimana cara memperoleh modal usaha agar usaha yang mereka jalankan dapat tumbuh dan berkembang. Agar akses kelembaga keuangan semakin mudah, peserta juga dibekali tentang cara-cara untuk memperoleh modal usaha dari pihak ketiga. Selama pelatihan, setiap selesai materi, para peserta diberikan pendampingan dalam penyusunan pengelolaan keuangan dan bagaimana melakukan transaksi secara online.

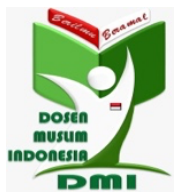

Copyright (C) 2021 The Author(s)

This article is licensed under CC BY 4.0 License

(cc) Br

https://dmi-journals.org/jai 


\section{Pendahuluan}

Salah satu tulang punggung perekonomian di Sumatera Barat adalah industri kreatif, dimana saat ini jumlah industri kreatif sudah mencapai 98\%. Kota Padang sebagai salah satu provinsi di Sumatera Barat juga banyak memiliki sentra-sentra industri kreatif, seperti industri kerajinan sulaman dan bordir, fashion, desain, penerbitan dan percetakan, serta makanan, yang banyak tersebar di sebelas kecamatan di kota Padang.

Salah satu industri kerajinan tangan yang ada di kota Padang adalah kerajinan sulaman dan bordir. Berdasarkan hasil penelitian (Rasyid, 2016) yang dilakukan kepada 60 unit usaha kerajinan sulaman dan bordir di kota Padang, ditemukan beberapa kendala dalam perkembangannya, dimana kendala utama adalah dalam hal permodalan dan selanjutnya dalam hal pemasaran. Permasalahan dalam hal permodalan ditemui modal yang dimiliki masih minim, dan pelaku usaha juga mengalami kesulitan dalam melakukan akses kepada lembaga pembiayaan. Hal ini disebabkan oleh masih rendahnya beberapa kinerja aspek yang dimiliki usaha tersebut, seperti aspek manajemen, target pasar, teknis, keuangan/cash flow, legalitas, dan inovasi. Padahal kinerja aspek-aspek tersebut menjadi pertimbangan lembaga keuangan ketika akan menyalurkan pembiayaan kepada pelaku usaha. Gambaran umum dari sumber permodalan usaha kerajinan sulaman dan bordir dikota Padang dapat dilihat pada Tabel 1 dibawah ini:

Tabel 1. Sumber Permodalan UKM Kerajinan

\begin{tabular}{lcc}
\hline \multicolumn{1}{c}{ Sumber Modal } & Jumlah (unit) & Persentase \\
\hline 100\% Modal sendiri & 27 & $45 \%$ \\
Lebih banyak modal sendiri dibanding & 28 & $46,67 \%$ \\
utang & & \\
50\% Utang dan 50\% Modal sendiri & 3 & $5 \%$ \\
Lebih banyak hutang dibanding modal & 2 & $3,33 \%$ \\
sendiri & & \\
Jumlah & 60 & $100 \%$ \\
\hline
\end{tabular}

Sumber : Pengolahan Data Primer (2016)

Dari tabel $1 \mathrm{di}$ atas terlihat sumber permodalan dari usaha kerajinan sebagian besar menggunakan modal sendiri. Minimnya akses pengusaha kerajinan di kota Padang terhadap lembaga keuangan dapat disebabkan karena masih rendahnya tingkat literasi keuangan dari pelaku usaha kerajinan. Literasi keuangan dapat diartikan sebagai pengetahuan keuangan, dengan tujuan mencapai kesejahteraan (Lusardi, 2007). Literasi finansial sebagai kemampuan seseorang untuk mendapatkan, memahami dan mengevaluasi informasi yang relevan untuk pengambilan keputusan dengan memahami konsekuensi finansial yang ditimbulkannya (Carolynne, 2000). Individu membutuhkan pengetahuan keuangan dasar serta skill untuk mengelola sumber daya keuangan secara efektif demi kesejahteraan hidupnya. Rendahnya literasi keuangan dapat mengakibatkan rendahnya akses ke lembaga keuangan dan menghambat kemakmuran. Literasi keuangan berupakan sebagai pengetahuan keuangan dengan tujuan mencapai kesejahteraan (Lusardi dan Mitchell, 2007).

Selama ini usaha kerajinan sulaman dan bordir yang ada di kota Padang masih memasarkan hasil produknya secara konvensional. Selain itu juga hanya mengandalkan para wisatawan yang berkunjung ke kota Padang, dan pada saat ada kegiatan pameran yang dilakukan oleh pemerintah atau asosiasi-asosiasi pengusaha. Hal ini berdampak 
pada omset penjualan sulaman dan bordir yang dapat dikatakan dalam siklus penjualan musiman. Adapun siklus penjualan sulaman dan bordir terbagi dalam beberapa kondisi. Kondisi penjualan ramai terjadi pada saat adanya pameran-pameran kerajinan. Pada bulan Syawal kondisi penjualan berada di level menengah. Selain bulan-bulan tersebut penjualan sulaman dan bordir mengalami sepi pesanan, sehingga omset penjualan menurun. Para pelaku usaha kerajinan tersebut sangat menginginkan pemasarannya meluas ke daerah-daerah lain, tetapi karena terkendala masalah dana untuk promosi maka keinginan tersebut belum dapat terwujud sampai saat ini. Jika permasalahan pendanaan dapat diatasi dan pemasaran produk dapat meluas maka akan dapat meningkatkan daya beli sehingga otomatis produksi meningkat dan hal ini akan membawa kesejahteraan masyarakat pelaku usaha sulaman dan bordir tersebut. Menurut Lusardi (2008) mengemukan bahwa rendahnya pengetahuan keuangan berpengaruh terhadap perencanaan keuangan masa depan, sedangkan ketidaktahuan tentang konsep dasar keuangan dapat berhubungan dengan rendahnya perencanaan investasi.

Pelaku usaha yang akan dijadikan mitra adalah usaha sulaman dan bordir dari usaha sulaman dan bordir Emiwati dan Nelvi. Dimana mitra ini dalam melakukan proses produksi hanya terbatas untuk kebutuhan lokal. Menurut mitra, hal ini disebabkan karena minimnya dana yang dimiliki untuk pnegembangan usaha dan juga untuk mempromosikan produk dan menjual produknya secara lebih luas. Minimnya modal yang dimiliki mitra karena kurangnya pengetahuan tentang pengelolaan keuangan yang terlihat dari perencanaan dan pengelolaan keuangan yang masih bersifat tradisional dan dalam bidang pemasaran terlihat mitra hanya melakukan penjualan secara konvensional. Berikut ini gambaran dari kegiatan usaha mitra yang dapat dilihat sebagai berikut:
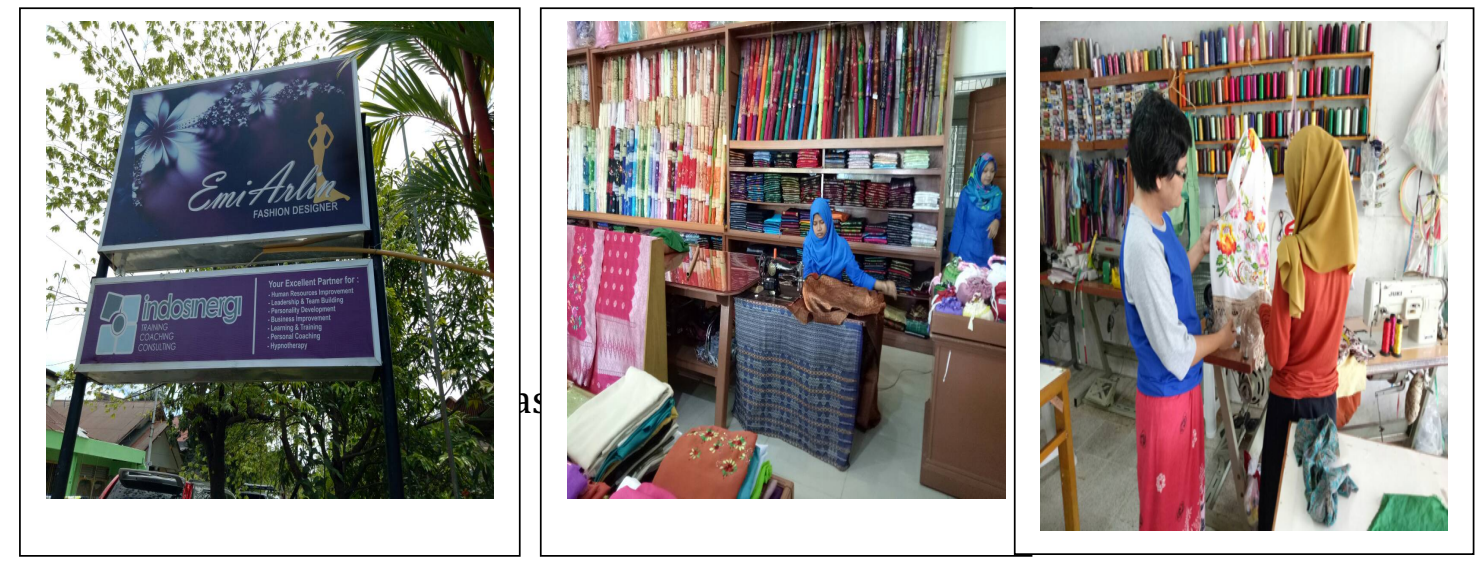

Gambar 1. Papan nama, proses produksi dan hasil produksi mitra.

Tujuan pengabdian masyarakat ini adalah:

1. Mitra usaha kerajinan sulaman dan bordir memiliki kemampuan literasi keuangan yang lebih baik, sehingga mampu menyusun, mengelola, dan membuat keputusan sumber pendanaan yang tepat.

2. Meningkatkan kemampuan mitra kerajinan sulaman dan bordir dalam meningkatkan akses ke lembaga-lembaga keuangan formal.

3. Meningkatkan pemahaman dalam melakukan perdagangan melalui internet ( $e$ commerce).

\section{Metode Pelaksanaan}


Kegiatan pengabdian kepada masyarakat yang berjudul "Pelatihan literasi Keuangan Dan E-Commerce Bagi Pelaku Ukm Kerajinan Sulaman Dan Bordir Di Kota Padang Sumatera Barat telah dilaksanakan pada hari Sabtu-Minggu tanggal 16-17 September 2017 di ruang pertemuan kantor PKK Kota Padang, Jl. Jend. Sudirman No 1 Padang, mulai jam 08.30 WIB sampai dengan selesai.

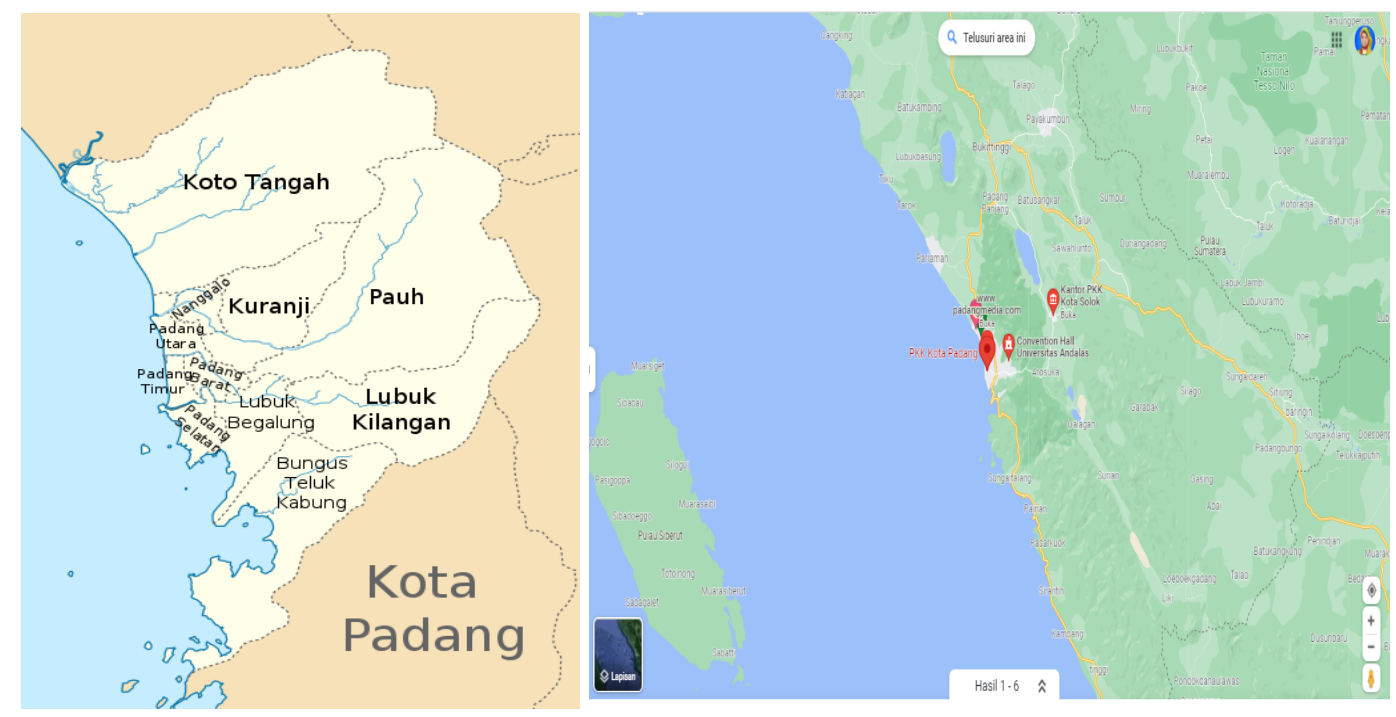

Gambar 2. Lokasi kegiatan pengabdian masyarakat di kantor PKK Kota Padang

Mitra kegiatan pelatihan ini adalah para pengrajin sulaman dan bordir, yang bergabung dalam kelompok Griya Busana Nayla dan Rumah Tenun dan Sulaman Nelvi, yang mana kedu kelompok tersebut berada dalam binaan PKK Kota Padang. Peserta berjumlah 15 orang yang berasal dari kedua kelompok mitra.

Metode pengabdian yang ditawarkan dalam guna menyelesaikan permasalahan yang dihadapi kelompok mitra dan sekaligus mendukung program ini adalah melalui:

1. Workshop Mengenai Literasi Keuangan

Secara umum kegiatan ini bertujuan untuk meningkatkan pengetahuan dan kemampuan kelompok mitra dalam menjalankan usaha mereka, agar semakin kompetitif. Workshop dilakukan dalam bentuk ceramah dan diskusi. Dimana materi akan disampaikan oleh narasumber dengan bantuan media power point, kemudian akan dilanjutkan dengan diskusi atas materi yang telah disampaikan. Kegiatan ini dihadiri oleh kelompok mitra dengan jumlah peserta sebanyak 15 orang.

2. Pendampingan dalam melakukan perdagangan melalui internet (Ecommerce) dengan membuatkan website yang dapat dikelola oleh kelompok mitra dalam pemasaran produknya.

Indikator keberhasilan setelah menjalankan kegiatan workshop ini, diharapkan para peserta dapat menemukan solusi dari beberapa masalah kelompok mitra, diantaranya adalah sebagai berikut : 
1. Memahami mengenai literasi keuangan. Pada akhir kegiatan $70 \%$ dari materi pelatihan mengenai literasi keuangan dapat dipahami oleh kelompok pengrajin sulaman dan bordir.

2. Peserta memiliki pengetahuan dan pemahaman dalam mencari alternative sumber-sumber pendanaan untuk pengembangan usaha. Pada akhir kegiatan $100 \%$ dari materi pelatihan mengenai sumber-sumber pendanaan dapat dikuasai oleh kelompok mitra.

3. Kelompok mitra memiliki pengetahuan dan pemahaman bagaimana cara untuk melakukan akses ke masing-masing lembaga keuangan untuk memperoleh sumber pendanaan tambahan bagi usaha mereka. Pada akhir kegiatan sekitar $60 \%$ materi pelatihan dapat dikuasai dengan baik oleh peserta.

Sebelum pelatihan dilaksanakan, tim kegiatan pengabdian masyarakat telah mendesain dan membuatkan website untuk dikelola dan digunakan oleh kelompok mitra sebagai sarana promosi dan penjualan produk dengan nama website www.sulamankreative.com. Pada saat pendampingan, mitra dibimbing dalam pengoperasian web tersebut, mulai dari bagaimana cara mengupload produk, melakukan link web ke media sosial lainnya hingga cara untuk melakukan maintenance terhadap web tersebut. Pendampingan ini dilakukan sampai anggota mitra berhasil melakukan upload terhadap produknya dengan munculnya produk yang mereka upload dihalaman web yang telah disediakan.

Disamping menyediakan web sebagai sarana penjualan dan promosi bagi mitra secara online, mitra juga diberikan pendampingan untuk melakukan penjualan secara online dengan bergabung ke online-online store yang sudah ada seperti lazada, bukalapak, dan lain-lain agar produk yang dihasilkan mitra dapat menjangkau pasar yang lebih luas. Pendampingan dilakukan untuk peningkatan pengetahuan dan keterampilan para peserta mengenai optimalisasi pemamnfaatan e-commerce dalam memasarkan, sehingga dengan metode ini para peserta setelah mengikuti kegiatan pengabdian diharapkan akan mampu mengaplikasikan berbagai pengetahuan tersebut pada kelompok usaha mereka. Dalam kegiatan ini para Tim pelaksana dan instruktur akan mendampingi para peserta sehingga para peserta akan lebih mampu dan terampil.

\section{Hasil dan Pembahasan}

Peserta pelatihan yang dilibatkan dalam kegiatan pengabdian ini adalah para pelaku usaha kecil dan menengah di Kota Padang yang bergerak pada kerajinan sulaman dan bordir. Peserta dari kegiatan pengabdian ini berjumlah 15 orang. Mereka datang melalui undangan secara resmi melalui tim penggerak PKK Kota Padang. Para pemateri dan instruktur yang terlibat dalam kegiatan ini memberikan pengetahuan dan wawasan tentang merek dagang yang mana pemateri merupakan orang dan instruktur yang kompeten dibidangnya.

Peserta yang diundang untuk mengikuti pelatihan ini sangat bersemangat saat diundang untuk mengikuti pelatihan, hal ini dapat dilihat dari respon yang cukup antusias yang ditunjukkan oleh para peserta tersebut yang datang tepat waktu pada jadwal yang ditetapkan, dan jumlah utusan yang hadir melebihi dari undangan yang disebarkan, karena ternyata pihak PKK Kota Padang juga mungundang para pengrajin sulaman dan bordir yang tidak tergabung dalam kelompok mitra dengan harapan mereka dapat 
menyebarkan pengertahuan ini kepada pengrajin lainnya yang tidak mengikuti pelatihan ini.

Dalam pelaksanaan kegiatan pelatihan ini, para pengrajin sulaman dan bordir diberikan pengetahuan dan wawasan mengenai apa itu literasi keuangan melalui inklusi keuangan dan bagaimana cara memperoleh modal usaha agar usaha yang mereka jalankan dapat tumbuh dan berkembang. Jadi, setelah peserta mengetahui mengenai literasi keuangan terutama tentang inklusi keuangan, diharapkan akan meningkatkan akses masyarakat terhadap lembaga, produk, dan layanan jasa keuangan. Selain itu, agar akses kelembaga keuangan semakin mudah, peserta juga dibekali tentang cara-cara untuk memperoleh modal usaha dari pihak ketiga. Selain dari segi keuangan, para pengrajin juga diperkenalkan untuk melakukan perdagangan secara online dengan membuatkan mereka sebuah website dan cara-cara untuk berjualan dengan bergabung kepada tooktoko online yang sudah ada saat ini. Selama pelatihan, setiap selesai materi, para peserta diberikan pendampingan dalam penyusunan pengelolaan keuangan dan bagaimana melakukan transaksi secara online.

Sebelum memulai acara, pelaksana melakukan tanya jawab dengan peseta terkait dengan pemahaman peserta tentang literasi keuangan dan penjualan secara online.

Tabel 2. Kuisioner Pemahaman Mengenai literasi keuangan dan e-commerce Sebelum Pelatihan

\begin{tabular}{|c|c|c|c|c|c|}
\hline No. & Pertanyaan & Ya & $\%$ & Tidak & $\%$ \\
\hline 1 & $\begin{array}{l}\text { Apakah Ibu-ibu sudah pernah mendengar } \\
\text { mengenai literasi keuangan? }\end{array}$ & 0 & $0 \%$ & 15 & $100 \%$ \\
\hline 2 & $\begin{array}{l}\text { Apakah Ibu-ibu pernah melakukan } \\
\text { pinjaman sebagai tambahan modal kerja ke } \\
\text { lembaga keuangan selain bank? }\end{array}$ & 5 & $33,33 \%$ & 10 & $66,67 \%$ \\
\hline 5 & $\begin{array}{l}\text { Apakah Ibu-ibu sudah memiliki sarana dan } \\
\text { media yang memadai untuk } \\
\text { mempromosikan produk dari kelompok } \\
\text { usaha Ibu-ibu? }\end{array}$ & 6 & $40 \%$ & 60 & $60 \%$ \\
\hline 6 & $\begin{array}{l}\text { Apakah Ibu-ibu sudah memiliki } \\
\text { pengetahuan tentang e-commerce? }\end{array}$ & 3 & $20 \%$ & 12 & $80 \%$ \\
\hline 7 & $\begin{array}{l}\text { Apakah Ibu-ibu sudah memanfaatkan } e \text { - } \\
\text { commerce sebagai media promosi dari } \\
\text { produk kelompok usaha Ibu-ibu? }\end{array}$ & 0 & $0 \%$ & 15 & $100 \%$ \\
\hline 8 & $\begin{array}{l}\text { Apakah menurut Ibu-ibu perlu } \\
\text { memaksimalkan pemanfaatan media } e^{-} \\
\text {commerce untuk promosi guna } \\
\text { meningkatkan pendapatan dari kelompok } \\
\text { usaha Ibu-ibu? }\end{array}$ & 15 & $100 \%$ & 0 & $0 \%$ \\
\hline
\end{tabular}

Berdasarkan jawaban yang diberikan oleh peserta sebelum pelatihan terlihat bahwa sebelum pelatihan pengetahuan peserta terhadap literasi keuanan tidak ada sama sekali, sehingga ini menunjukkan gambaraan awal bahwa peserta memang mengalami kesulitan dalam pendanaan untuk pengembangan usaha mereka. Sedangkan pengetahuan peserta tentang e-commerce masih terbatas, ini ditunjukkan oleh jawaban pertanyaan keena, dimana persentase jawaban peserta hanya sebanyak $20 \%$. Bahkan 
belum ada diantara peserta yang memanfaatkan e-commerce sebagai sarana promosi untuk produk mereka.

Kegiatan pelatihan ini dimulai dengan kata sambutan dari Ketua Pelaksana kegiatan yakni ibu Rosyeni Rasyid, SE, ME. Setalah acara pembukaan berlangsung, kemudian dilanjutkan pada kegiatan pertama, yaitu Workshop. Dimana workshop merupakan kegiatan yang dilakukan dalam bentuk ceramah dan diskusi. Pada kegiatan ini terdapat dua materi, yaitu: tentang literasi keuangan dan proses bagaimana mengajukan pinjaman ke lembaga-lembaga keuangn. Setiap materi akan disampaikan oleh pameteri yang berbeda dan berkompetensi dalam bidangnya masing-masing.

Pemaparan materi pertama sekaligus diskusi, yaitu; tentang literasi keuangan ang lebih difokuskan tentang inklusi keuangan disampaikan oleh Ibu Dina Patrisia, Ph.D, yang dilaksanakan setelah acara pembukaan pada hari Sabtu tanggal 16 September 2017, mulai dari 9.30 WIB sampai 12.00 WIB. Menurut pemateri, inklusi keuangan menjadi tren paska krisis 2008 terutama didasari dampak krisis kepada kelompok ekonomi menengah kebawah (in the bottom of the pyramid) yang umumnya tidak memiliki akses dan layanan jasa lembaga keuangan (unbanked) yang tercatat sangat tinggi di luar negara maju. Sedangkan tujuan inklusi yakni untuk meningkatkan akses masyarakat terhadap lembaga, produk, dan layanan jasa keuangan. Selain itu, agar meningkatkan penyediaan, penggunaan, serta kualitas produk dan layanan jasa keuangan.

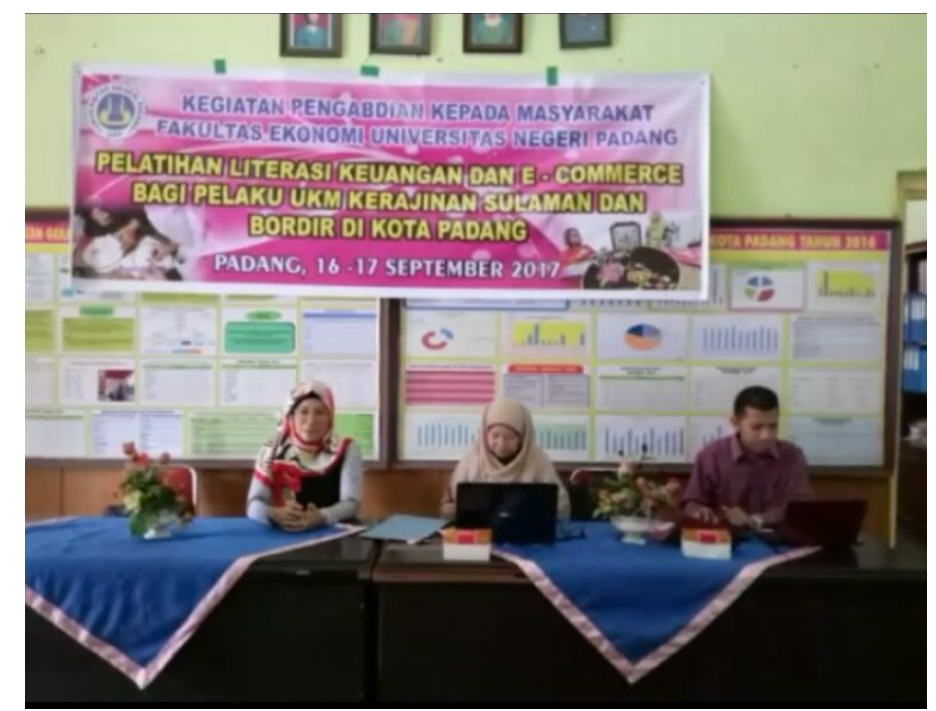

Gambar 3. Forum Kegiatan Pelatihan

Setelah peserta memperoleh pengetahuan mengenai literasi keuangan terutama inklusi keuangan, maka agar materi pertama tidaj terputus begitu saja, dilanjutkan dengan materi kedua agar materi pertama dapat teraplikasikan dengan baik oleh peserta. Materi kedua sebagai lanjutan dari materi pertama yaitu mengenai cara-cara memperoleh modal usaha yang disampaikan oleh Ibu Rahmiati, SE. M.Sc. 


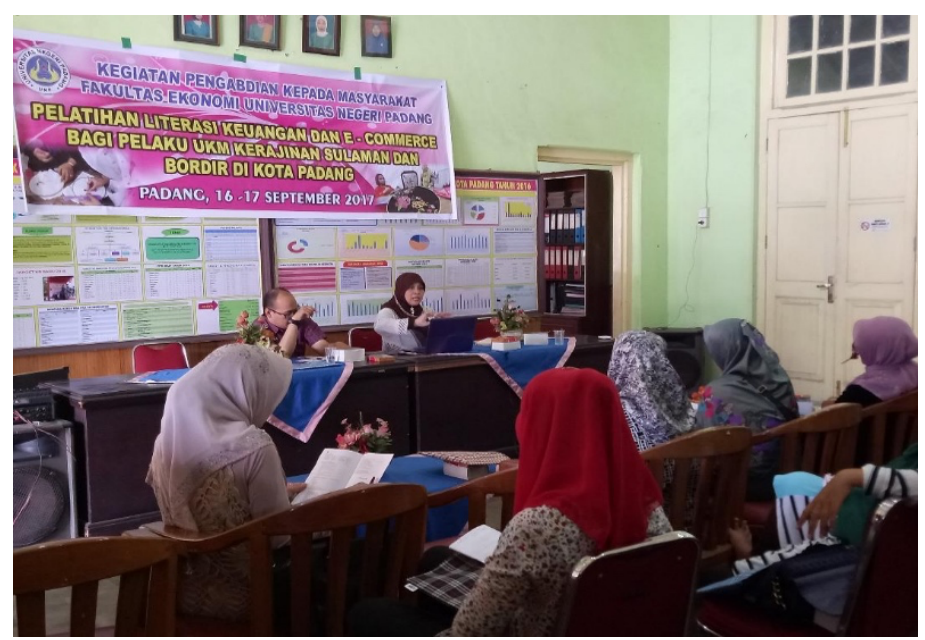

Gambar 4. Forum Kegiatan Pelatihan

Setelah workshop dilaksanakan pada tanggal 17 September 2017, dilanjutkan dengan kegiatan e-Commerce. Kegiatan e-commerce pertama adalah pemberian pelatihan kepada peserta akan web telah dibuatkan bagi peserta sebagai sarana penjualan online yang dapat mereka lakukan. Materi ini disampaikan oleh Bapak Agus Nurofik, S. Kom, MM. PAda pelatihan ini, peserta dibimbing bagaimana cara untuk mengupload produk yang akan dijual dihalaman web yang telah disediakan sampaikan dengan produk tersebut muncul dihalaman web tersebut untuk dijual. Adapun alamat web yang dibuatkan bagi peserta untuk penjualan secara online adalah www.sulamankreative.com. Dari web yang telah disediakan oleh panitia untuk selanjutnya dikelola oleh peserta sebagai sarana penjualan online mereka, web ini juga dapat digunakan sebagai media promosi bagi peserta. Melalui web ini, peserta diajarkan dan dilatih untuk membuat alamat web ini terkoneksi langsung ke media sosial yang ada seperti facebook.

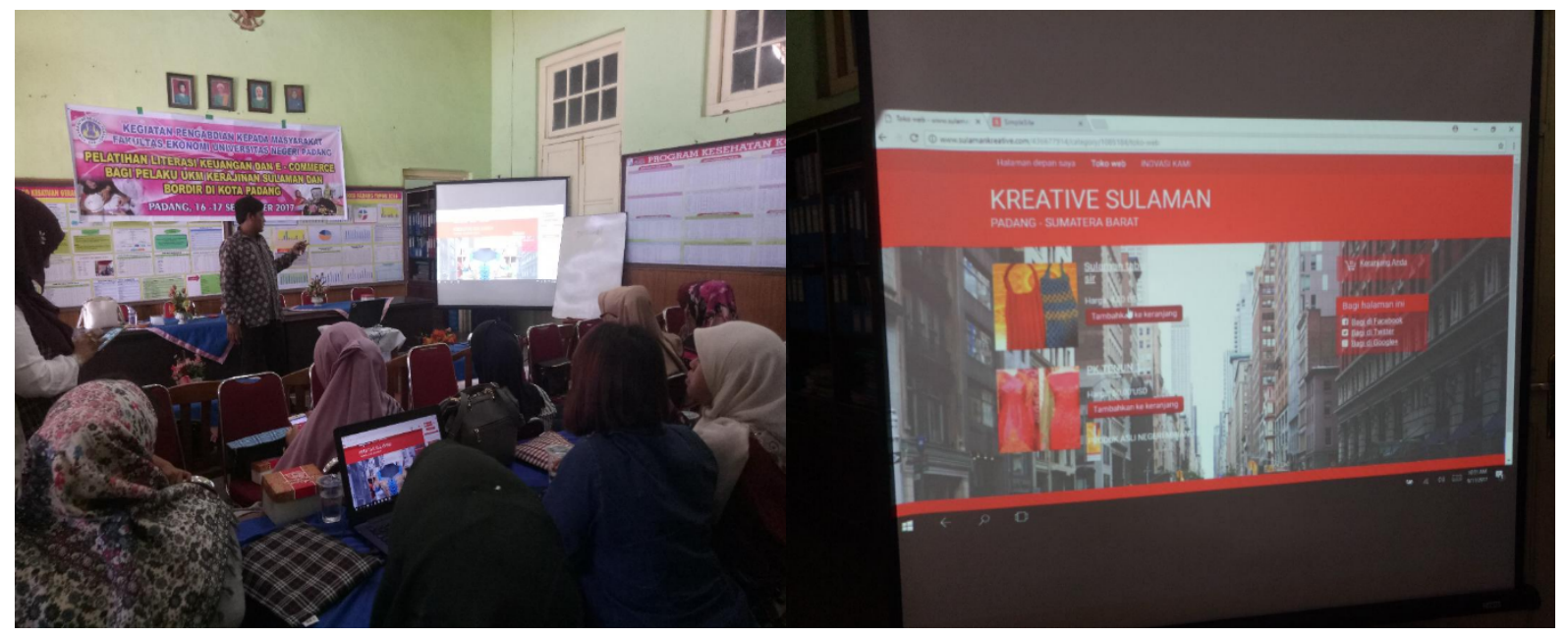

Gambar 5. Forum Kegiatan Pelatihan

Setelah peserta diberikan pelatihan mengenai bagaimana melakukan penjualan secara online pada web sendiri, maka selanjutnya materi kedua pada hari kedua pelatihan, peserta diberikan pelatihan untuk dapat melakukan penjualan melalui tokotoko online yang sudah ada, seperti pada bukalapak.com. Peserta dibekali pengetahuan tentang bagaimana cara-cara untuk bergabung, dan apa saja yang harus dilakukan agar dapat bergabung dengan toko online tersebut. Materi kedua ini disampaikan oleh Bapak Okki Trinanda, SE, MM.

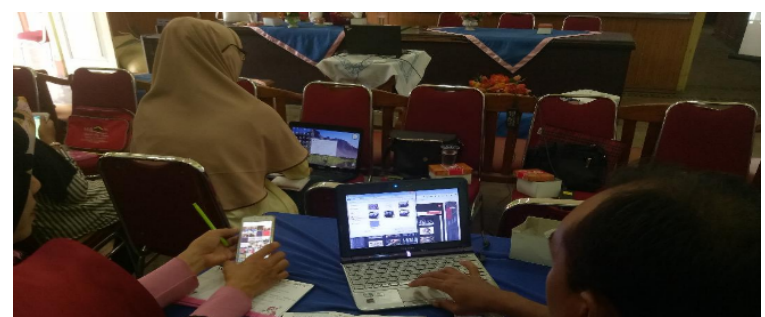


Gambar 6. Forum Kegiatan Pelatihan

Dengan selesainya penyampaian materi pengabdian yang dilakukan pada tanggal 16-17 September 2016, maka kegiatan pelatihan tetap berlanjut dalam bentuk program pendampingan. Kegiatan pendampingan dilaksanakan dua kali, yaitu pada tanggal 30 September dan 20 Oktober 2017. Pada program pedampingan ini tim pelaksana mendatangi peserta yang menjadi penanggung jawabpengelolaan website untuk mengetahui bagaimana pemanfaatan website yang telah ada sebagai sarana promosi dan penjualan serta meninjau apakah pengetahuan tentang literasi keuangan yang telah disampiakan kepada peserta memberikan dampak yang positif dalam pengelolaan keuangan usaha. Melalui program pedampingan, ini diharapkan terdapat peningkatan pengetahuan peserta mengenai literasi keuangan, dan para peserta semakin terampil dalam pemamnfaatan e-commerce guna memasarkan produk.

\section{Kesimpulan}

Dari kegiatan pengabdian kepada masyarakat yang berjudul pelatihan literasi keuangan dan e-commerce bagi pelaku UKM kerajinan sulaman dan bordir di Kota Padang Sumatera Barat dapat diketahui sebelum diadakannya pelatihan masih banyak peserta yang belum mengetahui tentang literasi keuangan dan bagaimana caranya untuk melakukan penjualan secara online, baik dengan memiliki web sendiri atau dengan cara bergabung pada took-toko online yang telah tersedia. Setelah diadakannya kegiatan pengabdian ini diharapkan peserta dapat mengetahui dan memahami tentang literasi keuangan dan cara melakukan penjualan secara online.

\section{Ucapan Terimakasih}

Ucapan terima kasih kepada Lembaga Penelitian dan Pengabdian Kepada Masyarakat (LPPM) Universitas Negeri Padang yang telah mendanai kegiatan pengabdian ini dan seluruh pihak yang telah mendukung pelaksanaan kegiataan ini sehingga dapat terlaksana dengan baik.

\section{Referensi}

Carolynne, L. J. (2000). Conceptualizing Financial Literacy. Businee School Research Series.

Lusardi, A. \& Mitchell, O.S. (2007). Baby Boomer retirement security: The roles of planning,financial literacy, and housing wealth. Journal of Monetary Economics, 205224.

Lusardi, A. (2008). Household Saving Behavior: The Role of Literacy, Information and Financial Education Programs. n. 13824.: NBER Working Paper. 
Vol. 1. No. 4 Desember 2021

Rasyid, R. (2016). Aspek Bias dalam pengambilan keputusan pendanaan dan pengaruhnya terhadap perkembangan usaha kerajinan di kota Padang Sumatera Barat. Padang: Fakultas Ekonomi Universitas Negeri Padang. 